\title{
PENGEMBANGAN PERANGKAT PEMBELAJARAN FISIKA MODEL INKUIRI TERBIMBING SEBAGAI UPAYA MENINGKATKAN HASIL BELAJAR SISWA PADA MATERI KALOR DI SMA
}

\author{
Moh. Luqman Hakim', ${ }^{1)}$ Prabowo' ${ }^{2)}$, Leny Yuanita ${ }^{3)}$ \\ ${ }^{1)}$ Mahasiswa Program Studi Pendidikan Sains, Program Pascasarjana Universitas Negeri Surabaya \\ ${ }^{2), 3)}$ Dosen Pascasarjana Prodi Pendidikan Sains Univesrtitas Negeri Surabaya \\ E-mail: luqmanhyakub@gmail.com
}

\begin{abstract}
The purpose of this research is produce physics learning material through guided inquiry model that valid, practical, and effective to improve learning outcomes of senior high school students. The development of learning material used the Kemp model and was tested X of SMA Hangtuah 1 Surabaya second semester in academic year 2013/2014 with One-Group PretestPosttest Design. Data of the study collected through observation, test, and questioner. The results of this research are: 1) Learning material developed has a valid category. 2) Learning material in terms of a practical category in feasibility of lesson plans and the students' activities in accordance with steps of guided inquiry model. 3) The learning material effectiveness in terms of: (a) the increasing of students learning outcomes seen from exhaustiveness of indicator, individual, and classical; (b) the increasing of students' comprehensiveness seen from high level of gain; (c) The students' responds toward material and implementation of learning are very positive. Based on the findings of the study, It's conclusion that the learning material through guided inquiry model are valid, practical, and effective to increasing students' learning outcomes. It showed through the students' comprehensiveness of the concept, psychomotor skills and character, which are students' discipline and responsible.
\end{abstract}

Keywords: Learning Material, Guided Inquiry, Learning Outcomes.

Abstrak: Penelitian ini bertujuan untuk menghasilkan perangkat pembelajaran fisika model inkuiri terbimbing yang valid, praktis, dan efektif sebagai upaya untuk meningkatkan hasil belajar siswa SMA. Pengembangan perangkat pembelajaran menggunakan model Kemp dan diujicobakan di kelas X SMA Hangtuah 1 Surabaya semester genap tahun ajaran 2013/2014 dengan One-Group Pretest-Posttest Design. Pengumpulan data menggunakan metode observasi, tes, dan angket. Temuan hasil penelitian, yaitu: 1) Perangkat pembelajaran yang dikembangkan berkategori valid; 2) Kepraktisan perangkat pembelajaran ditinjau dari keterlaksanaan RPP berkategori baik dan sesuai dengan tahap-tahap pada model inkuiri terbimbing; dan 3) Keefektifan perangkat pembelajaran ditinjau dari: (a) Peningkatan hasil belajar siswa terlihat dari ketuntasan indikator, individual, dan klasikal; (b) Peningkatan kemampuan pemahaman konsep siswa terlihat dari gain dengan kategori tinggi; dan (c) Respon siswa terhadap perangkat dan pelaksanaan pembelajaran sangat positif. Berdasarkan hasil temuan dalam penelitian ini, disimpulkan bahwa perangkat pembelajaran IPA Fisika dengan model inkuiri terbimbing, praktis dan efektif untuk meningkatkan hasil belajar siswa yang ditunjukkan oleh pemahaman konsep siswa, keterampilan psikomotor siswa, dan karakter siswa yang meliputi disiplin dan tanggung jawab siswa.

Kata Kunci: Perangkat Pembelajaran, Inkuiri Terbimbing, Hasil Belajar

\section{PENDAhUluan}

Kehidupan masyarakat maju telah menuntut berbagai perubahan mendasar pada bidang pendidikan. Di Indonesia, terdapat beberapa upaya yang telah dilakukan oleh para pelaku pendidikan sebagai upaya untuk meningkatkan mutu pendidikan. Upaya-upaya tersebut antara lain: Perubahan kurikulum, Aplikasi model pembelajaran yang disadur dari negara maju, Peningkatan keefektifan bahan ajar, dan Penambahan fasilitas pembelajaran. Menurut Mulyasa (2013), pemerintah juga telah melakukan upaya penyempurnaan sistem pendidikan baik melalui penataan perangkat lunak (software) maupun perangkat keras (hardware), yang meliputi dikeluarkanya Undang-Undang Sistem Pendidikan Nasional pada tahun 2003, dan Peraturan Pemerintah No. 19 tahun 2005 tentang Standar Nasional Pendidikan (SNP), yang telah dilakukan penataan kembali dalam Peraturan Pemerintah No. 32 tahun 2013. Pada kurikulum 2013, pemerintah telah menerapkan suatu kurikulum yang berbasis kompetensi sekaligus berbasis karakter (competency and character basic curriculum), yang dapat membekali siswa dengan berbagai sikap dan kemampuan yang sesuai dengan tuntutan 
perkembangan zaman dan tuntutan teknologi. Penerapan kurikulum 2013 sangat penting, guna menjawab tantangan arus globalisasi, berkontribusi pada pembangunan masyarakat dan kesejahteraan sosial, lentur dan adaptif terhadap berbagai perubahan.

Hasil belajar siswa pada mata pelajaran fisika yang rendah tidak hanya dipengaruhi oleh ketidakmampuan siswa menerima pelajaran yang disampaikan oleh guru, tetapi juga dipengaruhi oleh kemampuan guru dalam mengelola kegiatan belajar mengajar. Hamalik (2006) menyatakan guru bertanggung jawab menyesuaikan semua situasi belajar dengan minat, latar belakang, dan kematangan siswa.

Guru dapat menggunakan banyak model dalam menyampaikan materi pelajaran, salah satunya melalui inkuiri terbimbing. Menurut Vajoczki (2011) model pembelajaran inkuiri merupakan suatu model pembelajaran yang berorientasi pada proses dan keahlian untuk melakukan penelitian. Kuhlthau (2012) menyatakan bahwa inkuiri terbimbing dapat membantu siswa untuk berlatih dalam suatu tim, mengembangkan kompetensi dalam penelitian, pengetahuan, motivasi, kemampuan menulis, pembelajaran kooperatif dan keterampilan sosial. Siswa dapat menemukan konsep atau pengetahuan baru melalui proses hands-on activity yang terdapat pada model inkuiri terbimbing. Selain itu, siswa dapat dilatih untuk dapat memiliki karakter tanggung jawab dan disiplin pada saat kegiatan pengamatan berlangsung melalui inkuiri terbimbing,. Pentingnya pendidikan karakter pada siswa didukung oleh hasil penelitian Heckman, James \& Carneiro, Pedro (2003) yang menyimpulkan bahwa kecerdasan intelektual seseorang (verbal dan logis-matematis) hanya memberikan kontribusi $20 \%$ saja dari keberhasilan seseorang di masyarakat, sedangkan $80 \%$ lebih banyak ditentukan oleh kecerdasan emosi seseorang tersebut.

Berdasarkan latar belakang yang telah dipaparkan, maka penulis merasa perlu untuk melakukan penelitian untuk menjajaki pengaruh pembelajaran inkuiri terbimbing dengan melihat dampaknya terhadap hasil belajar siswa. Penelitian ini diberi judul "Pengembangan Perangkat Pembelajaran Fisika Model Inkuiri Terbimbing Sebagai Upaya Meningkatkan Hasil Belajar Siswa Pada Materi Kalor Di SMA". Perangkat pembelajaran yang dikembangkan meliputi: Rencana Pelaksanaan Pembelajaran (RPP), buku ajar siswa, Lembar Kerja Siswa (LKS), dan instrumen evaluasi.

\section{METODE PENELITIAN}

Rancangan penelitian ini menggunakan one group pretest-posttest design. Dalam penelitian ini, perangkat akan melalui uji dengan replikasi tiga kali/kelas. Populasi dan sampel yang digunakan adalah siswa kelas
$\mathrm{X}$ SMA Hangtuah 1 Surabaya tahun pelajaran 2013/2014. . Teknik pengumpulan data yang digunakan dalam penelitian ini adalah pengataman, tes, dokumentasi, dan angket respon siswa. Instrumen yang dikembangkan oleh peneliti berupa lembar validasi perangkat, lembar pengamatan keterlaksanaan RPP, lembar pengamatan keterampilan psikomotor siswa, lembar pengamatan sikap siswa, lembar angket respon siswa, dan lembar pengamatan kendala-kendala yang dihadapi selama proses pembelajaran. Teknik analisis data yang digunakan peneliti dalam penelitian ini adalah analisis dekriptif kuantitatif. Peneliti mendeskripsikan data yang telah terkumpul secara kuantitatif agar dapat dilakukan analisis statistik.

\section{HASIL PENELITIAN DAN DISKUSI}

Hasil penelitian ini ada tiga, yaitu: validitas perangkat pembelajaran, kepraktisan perangkat pembelajaran yang ditunjukkan oleh keterlaksanaan RPP dan kendala pembelajaran, dan keefektifan perangkat pembelajaran yang ditunjukkan oleh hasil belajar siswa dan respon siswa. Uraian lengkapnya adalah sebagai berikut:

\section{A. Validitas Perangkat Pembelajaran}

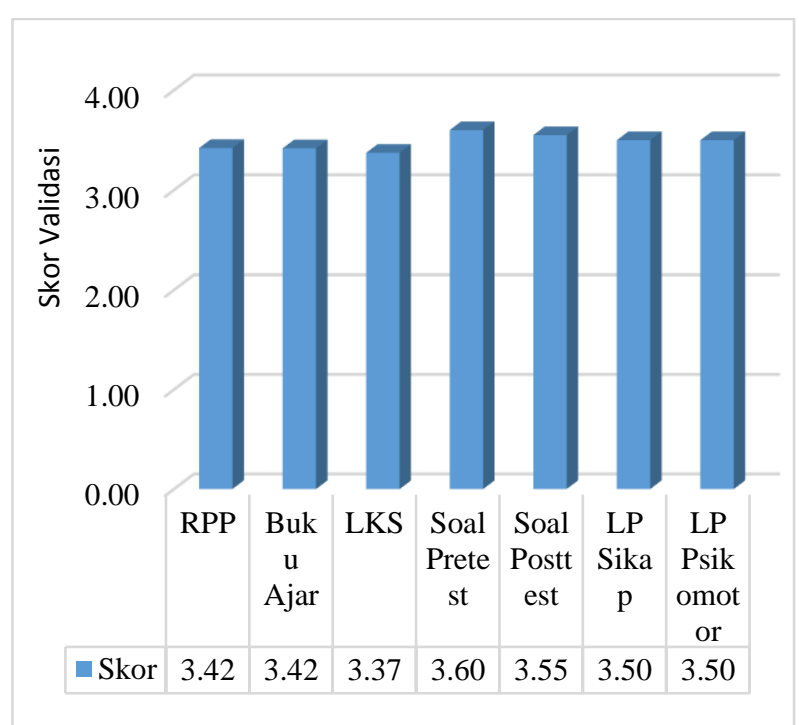

Gambar 1. Hasil Validitas Perangkat yang dikembangkan peneliti.

Gambar 1 menunjukkan bahwa hasil pengembangan perangkat pembelajaran yang dikembangkan oleh peneliti layak untuk digunakan dalam pembelajaran. Kelayakan perangkat pembelajaran dapar dilihta berdasarkan hasil validitas perangkat yang mendapat kategori valid.

\section{B. Keterlaksanaan RPP}




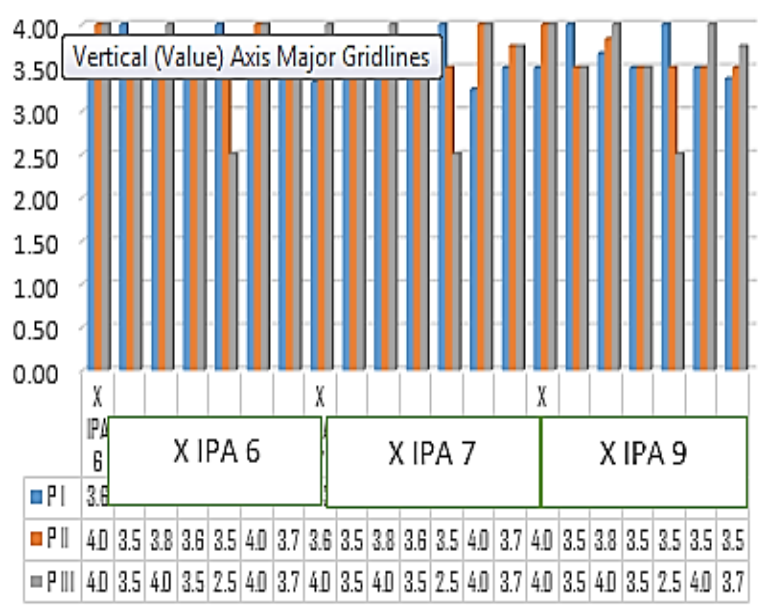

Gambar 2. Hasil Keterlaksanaan RPP

Semua tahap-tahap kegiatan yang ada di RPP pada uji coba II terlaksana dg baik dan rata-rata reliabilitas replikasi I adalah sebesar 98,06\%, replikasi II sebesar 96,44\%, dan replikasi III sebesar 97,69\%.

\section{Hasil Belajar Siswa}

Pada penelitian ini, hasil belajar terbagi kedalam ketiga ranah yaitu kognitif, sikap, dan keterampilan psikomotor. Uraian tiap ranah adalah sebagai berikut:

\section{a. Hasil Belajar Kognitif Siswa}
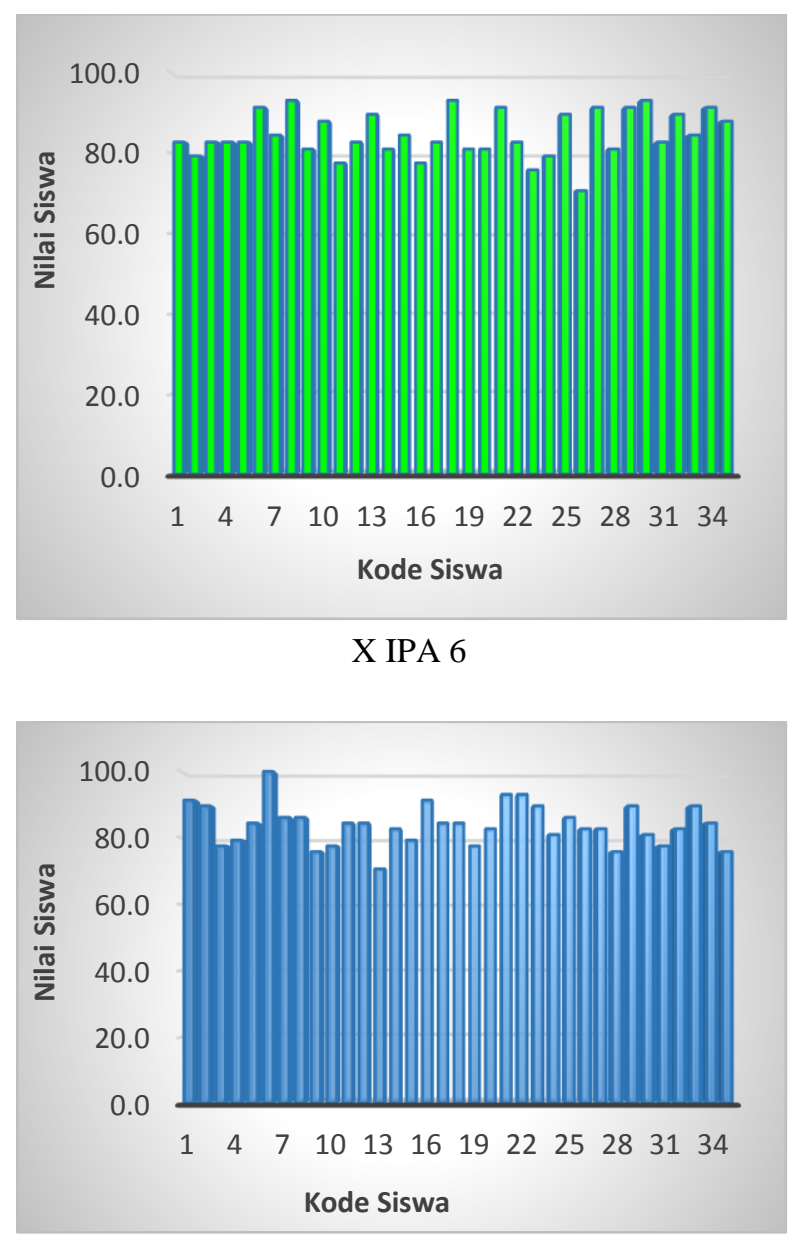

X IPA 7

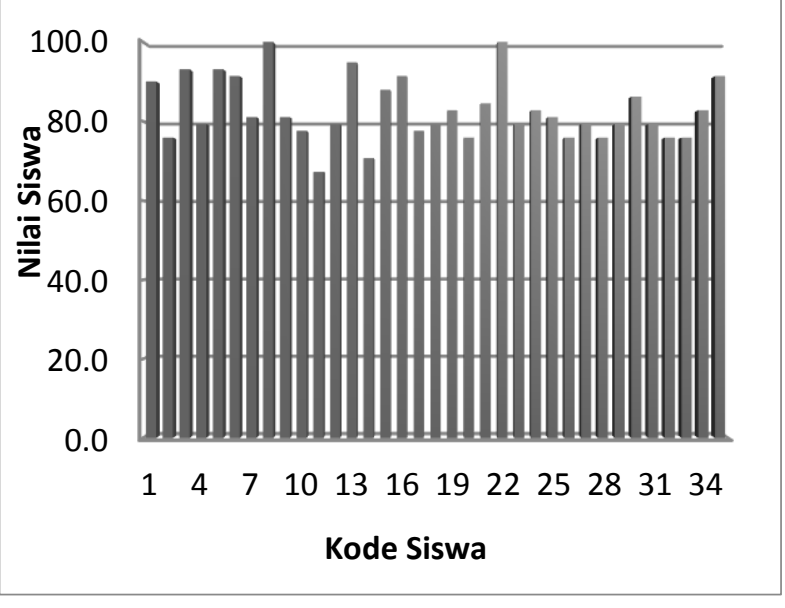

\section{IPA 9}

Gambar 3. Grafik nilai kognitif siswa pada uji coba II

Berdasarkan Gambar 3 dapat diketahui bahwa pembelajaran dengan menggunakan model inkuiri terbimbing dapat meningkatkan hasil belajar kognitif siswa. Pada penelitian ini, hasil belajar kognitif siswa ditunjukkan oleh pemahaman konsep siswa. Temuan ini didukung oleh temuan Wang, Pi-Hsia., Yen, Yu-Ren., $\mathrm{Wu}$, Hui-Ju., and Wu, Pai-Lu. Uji U Mann-Whitney pada data gain ternormalisasi digunakan di dalam penelitian ini untuk mengetahui persamaan peningkatan pemahaman konsep siswa antara kelas yang satu dengan yang lain pada materi kalor. Dari hasil uji MannWhitney diperoleh bahwa pada kelas X IPA 6 dan X IPA 7, X IPA 6 dan X IPA 9 maupun kelas X IPA 7 dan $\mathrm{X}$ IPA 9 tidak terdapat perbedaan peningkatan pemahaman konsep siswa pada kelas tersebut (Lampiran 2f halaman 278-292). Persamaan peningkatan pemahaman konsep siswa pada kelas X IPA 6 dan X IPA 7, X IPA 6 dan X IPA 9 maupun kelas X IPA 7 dan X IPA 9 dapat disebabkan karena terjadinya persamaan pemahaman konsep siswa pada kelas tersebut.

\section{b. Hasil Belajar Sikap Siswa}

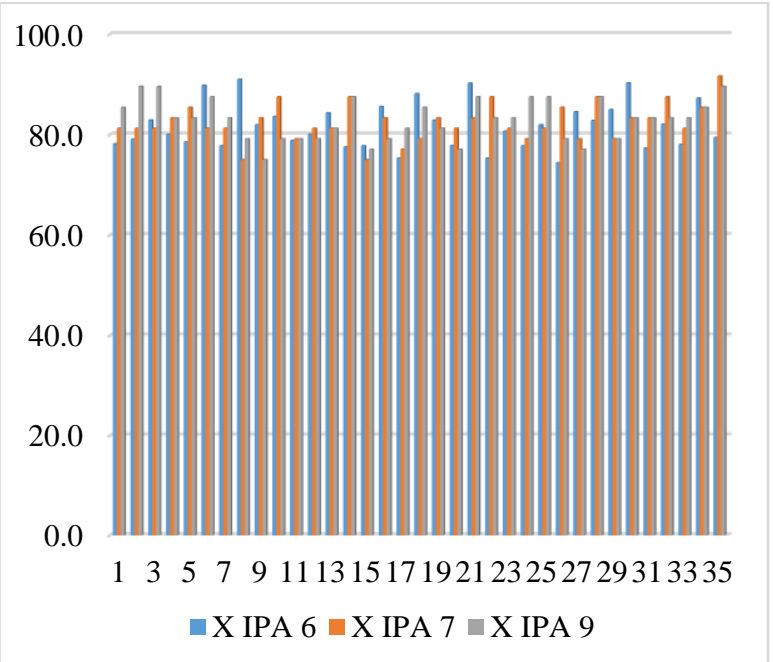

Gambar4.Grafik nilai sikap siswa pada uji coba II 
Berdasarkan data pada Tabel 4.36, Tabel 4.37, dan Tabel 4.38, telah mengindikasikan bahwa melalui pembelajaran dengan menggunakan model inkuiri terbimbing, karakter siswa dapat teramati dan dapat dikembangkan serta kedua karakter tersebut sudah membudaya. Hal ini sesuai dengan konsep belajar yang telah dikemukakan oleh Skinner yang menyatakan belajar adalah suatu perilaku. Pada teori perilaku, penggunaan pengulangan dan pelatihan dapat berimbas pada perilaku seseorang, sehingga perilaku yang diinginkan dapat menjadi sebuah kebiasaan (membudaya).

\section{c. Hasil Belajar Psikomotor Siswa}

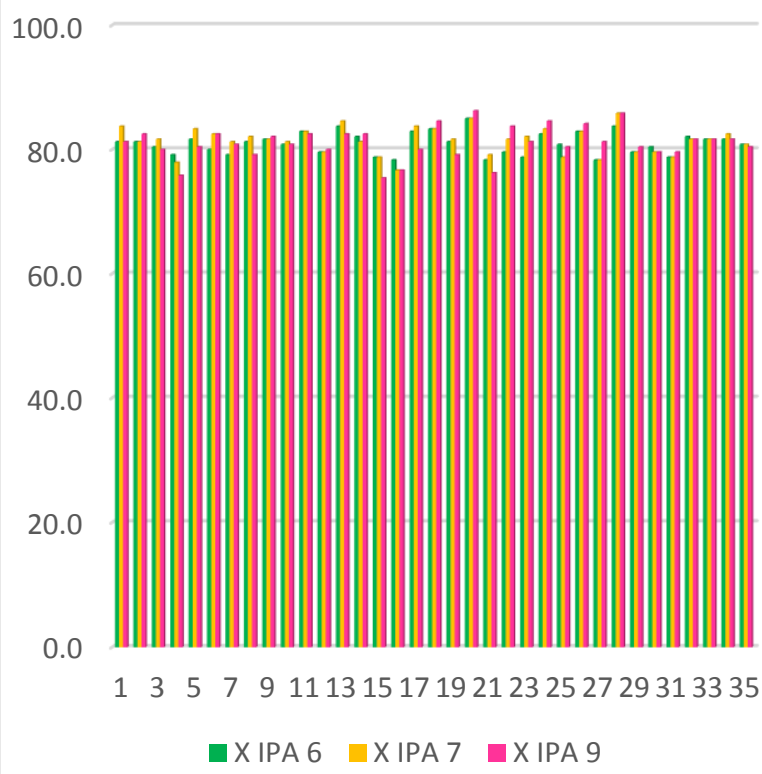

Gambar 5. Grafik nilai keterampilan psikomotor siswa pada uji coba II

Berdasarkan Gambar 5 dapat diketahui setelah penerapan model inkuiri terbimbing dalam pembelajaran, semua siswa dapat dinyatakan tuntas (KKM 75). Hal ini telah mengindikasikan bahwa siswa telah menguasai kompetensi psikomotorik yang dibelajarkan. Rata-rata peningkatan keterampilan psikomotor siswa pada kelas X IPA 6, X IPA 7, dan X IPA 9 adalah sama, dimana pada pertemuan awal rendah dan pada pertemuan akhir (pertemuan ketiga) adalah tinggi. Temuan ini sesuai dengan hasil penelitian Shih, J. L, Chuang, C. W, \& Hwang, G. J, (2010)

Hasil belajar seluruh siswa yang ditunjukkan oleh Gambar 3, Gambar 4, dan Gambar 5 mencapai nilai di atas 75 dengan kriteria tuntas. Siswa merespon positif terhadap pengembangan perangkat dan pelaksanaan pembelajaran model inkuiri terbimbing. Respon positif ini dapat dilihat dari Gambar 6 berikut.
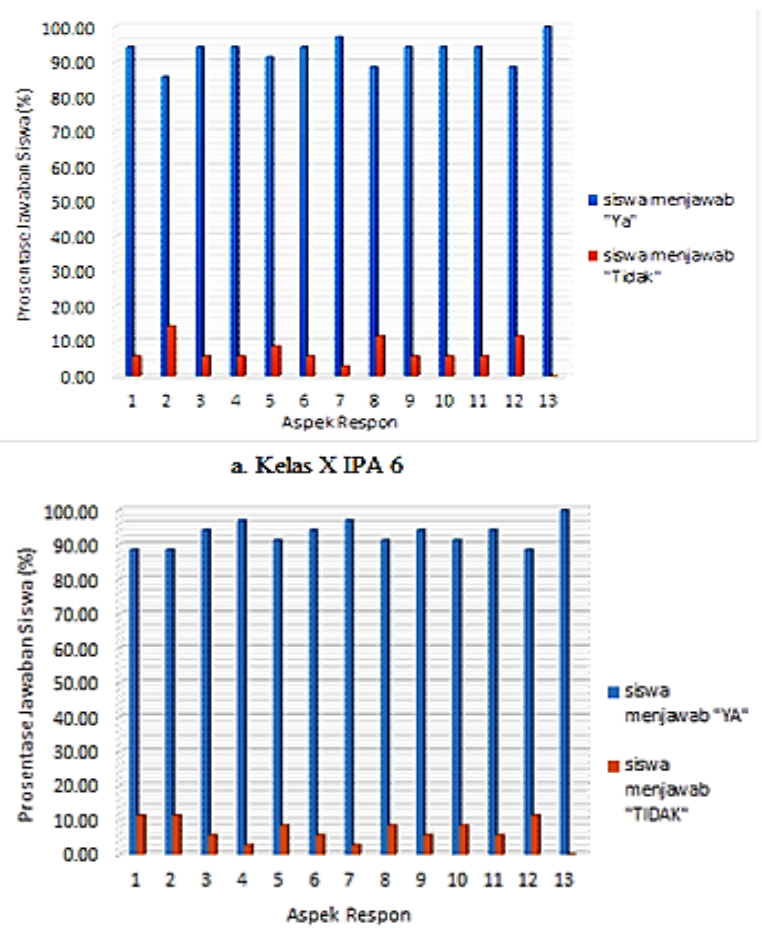

b. Kelas X IPA 7

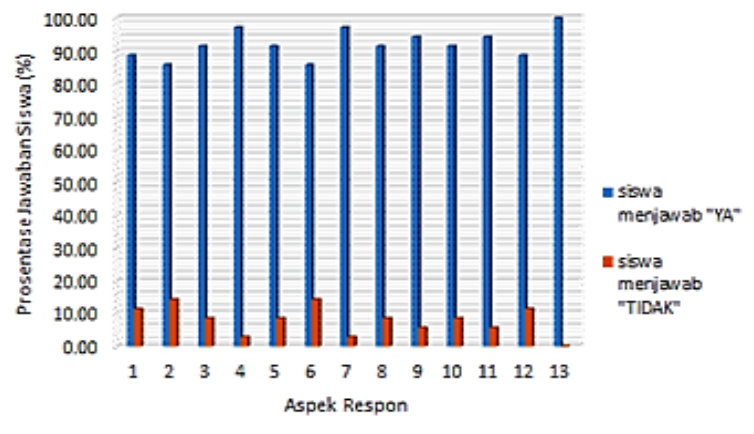

c. Kelas X IPA 9

Gambar 6. Grafik respon siswa pada uji coba II setelah mengikuti pembelajaran inkuiri terbimbing

Berdasarkan Gambar 6, dapat dikatakan bahwa respon siswa meningkat positif setelah diterapkanya model inkuiri terbimbing pada pembelajaran. Temuan ini konsisten dengan Gerald, Lee (2011), Manisah, R (2013), dan Burhanuddin (2014).

Tujuan akhir dari penelitian ini adalah tujuan penelitian ini adalah untuk menghasilkan perangkat pembelajaran fisika model inkuiri terbimbing yang valid, praktis, dan efektif sebagai upaya untuk meningkatkan hasil belajar siswa pada materi kalor di SMA. Kelayakan perangkat dapat dilihat berdasarkan hasil validitas perangkat pembelajaran. Kepraktisan perangkat dapat dilihat berdasarkan hasil keterlaksanaan RPP dan kendala yang muncul dalam pembelajaran. Keefektivan perangkat dapat dilihat berdasarkan hasil belajar siswa dan respon siswa. 


\section{KESIMPULAN}

\section{A. Simpulan}

Berdasarkan hasil penelitian dan pembahasan serta temuan-temuan di dalam penelitian yang telah diuraikan pada BAB IV dan V, dapat disimpulkan bahwa perangkat pembelajaran IPA Fisika dengan model inkuiri terbimbing, praktis dan efektif untuk meningkatkan hasil belajar siswa yang ditunjukan oleh pemahaman konsep siswa, keterampilan psikomotor siswa, dan sikap karakter siswa yang meliputi disiplin dan tanggung jawab siswa.

\section{B. Saran}

Pengembangan perangkat pembelajaran fisika model inkuiri terbimbing secara keseluruhan dapat meningkatkan hasil belajar fisika, sehingga diharapkan untuk penelitian selanjutnya, dapat digunakan pada materi fisika lain dan dilengkapi dengan media yang lebih menarik sehingga memudahkan siswa dalam memvisualisasikan konsep-konsep fisika yang masih bersifat abstrak.

\section{REFERENSI}

Gerald, Lee. (2011). "The Twin purposes of guided inquiry: guiding student inquiry and evidence based practice". Neals. Vol 30 No 1 February 2011.
Hamalik, O. (2006). Proses belajar mengajar. Bandung: Bumi Aksara.

Heckman, James and Carneiro, Pedro. (2003). Human capital policy. IZA Discussion Paper No. 821.

Kuhlthau, C. (2012). Guided inquiry design: A Framework for inquiry in your school. Santa Barbara: ABC-CLIO LCC.

Manisah, R. (2013). Pengembangan perangkat pembelajaran berorientasi keterampilan proses dengan model pembelajaarn inkuiri untuk meningkatkan pemahaman konsep materi kalor (Tesis magister pendidikan tidak diterbitkan). Universitas Negeri Surabaya.

Mulyasa, E. (2013). Pengembangan dan implementasi kurikulum 2013. Bandung: PT Remaja Rosdakarya.

Shih, J.-L., Chuang, C.-W., \& Hwang, G.-J. (2010). "An inquiry-based mobile learning approach to enhancing social science learning effectiveness". Journal Educational Technology \& Society, Vol 13 (4), 2010 Pp 5062.

Wang, Pi-Hsia., Yen, Yu-Ren., Wu, Hui-Ju., and Wu, Pai-Lu., (2013). "The Learning effectiveness of inquiry-based instruction among vocational high school students". Educational Research International Journal. Issue: Vol. No. 2, Number 2 